\title{
SOCIOLOGICKÉ VĚDY
}

UDC 311:338

DOI: $10.24045 / \mathrm{pp} .2017 .1 .23$

\section{INEQUALITY IN WAGES: THE STATISTICAL ASPECT}

E. V. Kabashova
Candidate of Economic Sciences

Bashkir State Agrarian University

Ufa, Republic of Bashkortostan, Russia

\begin{abstract}
The article is devoted to statistical analysis of inequality of wages of employees in Russia: reveals the concept and essence of inequality in wages, problems were studied statistics in the study of wages, given the system of statistical indicators and research methods. The classification of fields of statistical analysis of wage inequality: the object, subject and methods of research. In the article using the method of analytical groups and multiple correlation and regression analysis examined the influence of factors such as average wages, share of wages in the money income of the population, and others, on the degree of differentiation of wages of employees.
\end{abstract}

Key words: wage inequality; coefficient of funds; analytical grouping; correlation; regression; analysis.

Socio-economic reforms of 90-ies has led not only to a sharp fall in living standards of population, including wages, but also to a strong polarization [2]. Statistical studies of inequality of wages of employees are relevant and are of practical importance since the results help to identify the causes, factors of strong differentiation, its trends and to develop a forecast of its values for the future.

Under the wage differentiation of employees is understood to be due to objectively existing system of relations of production the result of the distribution of the wage fund, expressing the degree of irregularity of its distribution and manifested in the difference of the share of the wage fund received by different groups of workers.

A significant impact of wages on income inequality in general is due to a high share of wages in income of the population (in 20102015 of about $65 \%$ ). For comparison it may be noted that in the Russian Federation correlation between income inequality due to wage general inequality of monetary incomes is higher than for all other sources of income and is 0.88 .

The main tasks of statistical science in the study of inequalities of wages are:

- comparison of wage levels between individual categories of workers, enterprises of different ownership forms, as well as age groups of the population;

- grouping of workers by wage level, expressed in the construction of the interval of ranks distribution;

- calculation and interpretation of indicators of differentiation of population on wages (the coefficient of funds, the decile coefficient, the index of income concentration (Gini coefficient), and others);

- identification of socio-economic and demographic reasons and factors influencing the level of inequality in wages as well as their quantitative assessment;

- the study of the regional dynamics trends in indicators of wage differentiation of the population in the country in general and

\section{Paradigmata poznání. I. 20 I 7}


in the context of individual sociodemographic groups of the population;

- forecasting of indicators of wage differentiation of employees based on the application of statistical methods.

To solve the set task developed a system of statistical indicators of inequality of wages, which includes: the median level of wages, the coefficient of income concentration (Gini coefficient), coefficient of funds, the decile coefficient, the ratio of gross wages with subsistence minimum, coefficient of variation and others [3].

Indicators of wage inequality are investigated using a combination of statistical and econometric techniques and methods, in par- ticular: the method groups, method of general indicators, comparative principal component analysis of interregional differentiation [5], correlation and regression analysis, cluster analysis, index method, factor analysis, prediction for regression models, the construction of variational-dynamic tables [1] and the cumulative curves of Lorentz and others.

Thus, the research methodology inequality of wages of employees is very diverse, and is constantly being improved and updated. We have developed a classification of field of study inequality of wages depending on the following characteristics: 1) object of study; 2) the research subject; 3) the research method (figure 1) [3].

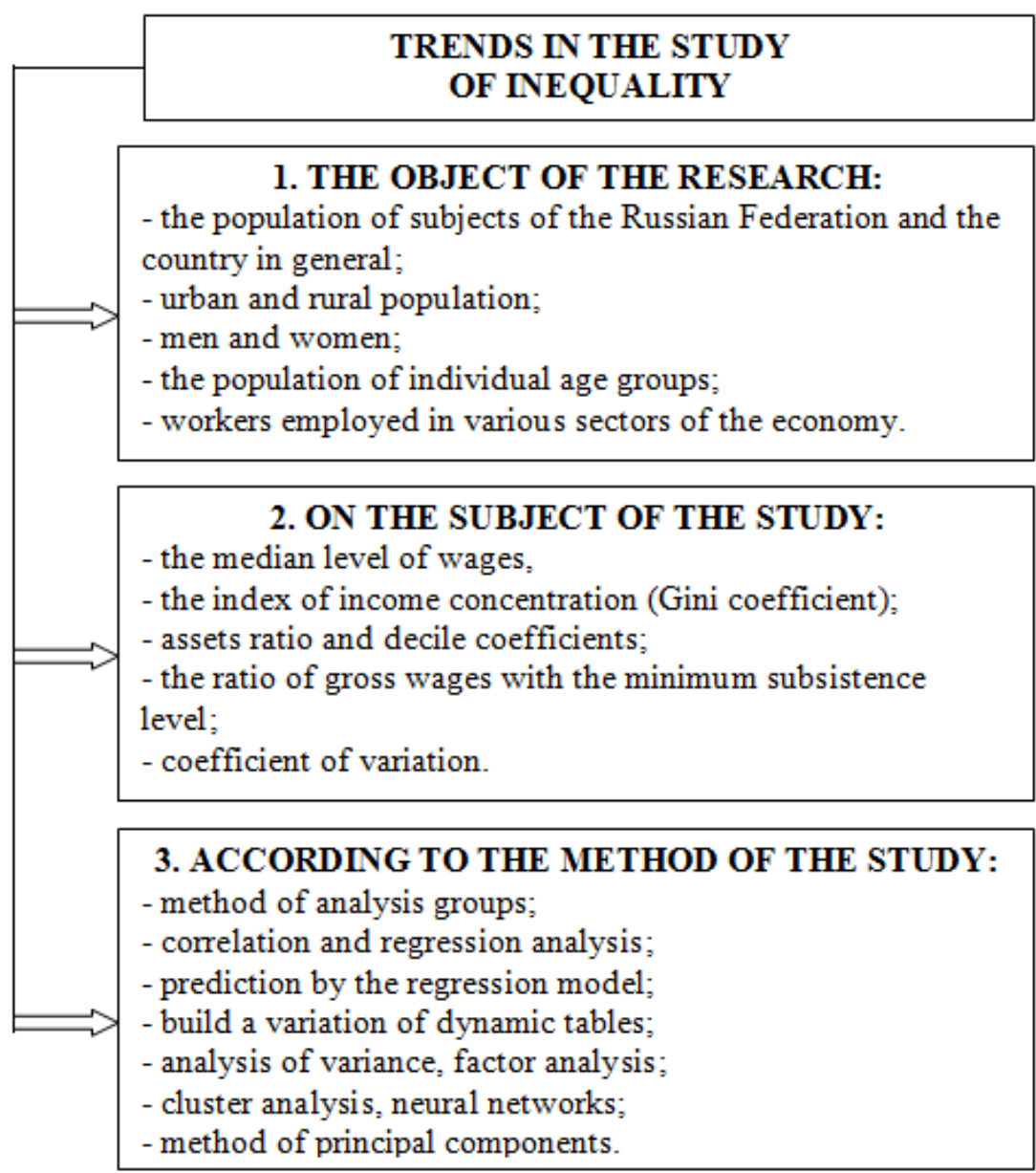

Figure 1. Classification of research directions inequality of wages 
To date, the statistical analysis aimed at identifying the relationship between wage differentiation and its defining factors, is highly relevant and has a practical significance.

In our study, for the analysis of wage differentiation selected 80 regions of the Russian Federation. The analysis was carried out according for 2014 year. As of the effective feature taken the ratio of funds, that is the ratio of the wage $10 \%$ the most provided population to $10 \%$ of the poorest.
All Russian regions were divided into three groups: low degree of differentiation, with moderate (average) differentiation and a high degree of wage differentiation. As the selected independent variables: X1 - average nominal accrued wages, rubles; $\mathrm{x} 2$ - the share of wages in the structure of money incomes of population, $\%$; X3 - the proportion of the number of workers with wages below the subsistence minimum, $\%$. The results of the analytical grouping of Russian regions on assets ratio is presented in table 1 .

The results of the analytical grouping of Russian regions by the level of differentiation of wages

\begin{tabular}{|l|c|c|c|c|c|c|}
\hline \multirow{2}{*}{ Group } & \multirow{2}{*}{$\begin{array}{l}\text { Group of regions } \\
\text { to assets ratio }\end{array}$} & \multirow{2}{*}{$\begin{array}{l}\text { The } \\
\text { number of } \\
\text { regions }\end{array}$} & \multicolumn{3}{|c|}{ The average values of the characteristics } \\
\cline { 4 - 7 } & $7,7-10,3$ & 28 & 9,7 & 22824,8 & 39,3 & 8,0 \\
\hline I & $10,3-12,9$ & 42 & 11,4 & 27038,6 & 41,8 & 9,9 \\
\hline II & $12,9-15,5$ & 9 & 14,2 & 31254,3 & 43,5 & 12,2 \\
\hline III & $\mathbf{x}$ & $\mathbf{7 9}$ & $\mathbf{1 1 , 1}$ & $\mathbf{2 6 0 2 5 , 4}$ & $\mathbf{4 1 , 1}$ & $\mathbf{9 , 5}$ \\
\hline Total & &
\end{tabular}

Thus, there is a direct correlation between the level of differentiation of wages and factors, namely: the higher the average salary, the higher the share of wages in the money income of the population, and more, the percentage of workers with wages below the subsistence level, the greater the degree of differentiation. So, in the third group of regions with the highest degree of wage differentiation, which includes: city of SaintPetersburg, Sakhalin oblast, Astrakhan oblast, Volgograd oblast, Dagestan, Chechnya, Tuva, Krasnoyarsk Krai, Zabaykalsky Krai, the coefficient of funds is more on $46,4 \%$, the average nominal wage - by $36,9 \%$, the share of wages in monetary income $-10.7 \%$, and the percentage of workers with wages below the subsistence minimum (living in poverty) - by $52,5 \%$ compared to the first group of regions [4].

To quantify the dependence of wage differentiation on factors of correlation and regression analysis in the whole of the Russian Federation and in the context of three educated groups, the results of which are presented in table 2 .

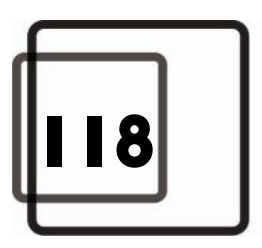


Estimation based on inequality of wages of factors

\begin{tabular}{|l|c|c|c|}
\hline Group & $\begin{array}{l}\text { Coefficient } \\
\text { of multiple } \\
\text { correlation }\end{array}$ & $\begin{array}{l}\text { Coefficient } \\
\text { of multiple } \\
\text { determination }\end{array}$ & $\begin{array}{l}\text { F-Fisher criterion } \\
\text { (actual) }\end{array}$ \\
\hline The first group & 0,538 & 0,289 & 3,257 \\
\hline $\begin{array}{l}\text { The regression } \\
\text { equation }\end{array}$ & \multicolumn{2}{|c|}{$\tilde{y}=7,5547+0,0004 x_{1}+0,0120 x_{2}+0,0980 x_{3}$} \\
\hline The second group & 0,310 & 0,096 & 1,351 \\
\hline $\begin{array}{l}\text { The regression } \\
\text { equation }\end{array}$ & \multicolumn{2}{|c|}{$\tilde{y}=10,3735-0,0006 x_{1}+0,0221 x_{2}+0,0126 x_{3}$} \\
\hline $\begin{array}{l}\text { The third group: } \\
X_{1}\end{array}$ & 0,426 & 0,181 & 1,552 \\
\hline$X_{2}$ regression & 0,038 & 0,001 & 0,010 \\
\hline$X_{3}$ & 0,426 & 0,181 & 1,553 \\
\hline $\begin{array}{l}\text { The } \\
\text { equation }\end{array}$ & \multicolumn{3}{|c|}{$\tilde{y}=15,2118-0,0003 x_{1} ; \tilde{y}=14,2949-0,0022 x_{2} ;$} \\
\hline $\begin{array}{l}\text { In the whole of } \\
\text { Russia }\end{array}$ & \multicolumn{3}{|c|}{$\mathbf{y}=13,7074+0,0405 x_{3}$} \\
\hline $\begin{array}{l}\text { The regression } \\
\text { equation }\end{array}$ & \multicolumn{3}{|c|}{$\tilde{y}=7,0547+0,0001 x_{1}-0,0081 x_{2}+0,1764 x_{3}$} \\
\hline
\end{tabular}

According to the table 2, we can conclude that in the Russian Federation the index of correlation, characterize the correlation between factor funds and the set of factors included in the equation, equal 0,589, which indicates a moderate relationship between the signs. It should be noted that given the nature of the distribution relationship, the bond is quite strong.

The quality of the constructed model as a whole evaluates the coefficient of determination, is equal 0,347 , that is $34,7 \%$ of the variation in wage differentiation due to variation of the above factors.

Thus, using a broad arsenal of statistical and econometric methods it is possible to conduct a comprehensive assessment of differentiation of incomes and wages of the population, an excessive degree of which contributes to the growth of economic stratification of the population and violates the terms of social justice.

\section{Bibliography}

1. Дубянская Г. Ю. Экономико-статистический анализ заработной платы в России. 1991-2001 гг. - М. : Финансы и статистика, 2003. -256 с.

2. Жеребин В. М. Индикаторы качества жизни населения // Вопросы статистики. - 2012. № 3. - C. 25-36.

3. Кабашова Е. В. Основные направления статистического исследования дифференциации заработной платы // Успехи современной науки, 2016. - Т. 3. - № 7. - С. 132-134.

4. Кабашова Е. В. Статистические методы в исследовании факторов дифференциации заработной платы // Лучшая научная статья 2016: сборник статей II Международного научно- 
практического конкурса. - Пенза, 2016. C. $16-21$.

5. Чернова, Т. В. Сравнительный анализ главных компонент межрегиональной дифференциации денежных доходов населения // Финансы и кредит. - 2003. - № 1(115). - С. 50-54.

6. Труд занятость в России. 2015 : Стат. сб. / Росстат. - М., 2015. - С. 274.

\section{Bibliography}

1. Dubjanskaja G. Ju. Jekonomiko-statisticheskij analiz zarabotnoj platy v Rossii. 1991-2001 gg. M. : Finansy i statistika, 2003. - 256 s.

2. Zherebin V. M. Indikatory kachestva zhizni naselenija // Voprosy statistiki. - 2012. - № 3. S. 25-36.
3. Kabashova E. V. Osnovnye napravlenija statisticheskogo issledovanija differenciacii zarabotnoj platy // Uspehi sovremennoj nauki, 2016. - T. 3. № 7. - S. 132-134.

4. Kabashova E. V. Statisticheskie metody v issledovanii faktorov differenciacii zarabotnoj platy // Luchshaja nauchnaja stat'ja 2016: sbornik statej II Mezhdunarodnogo nauchno-prakticheskogo konkursa. - Penza, 2016. - S. 16-21.

5. Chernova, T. V. Sravnitel'nyj analiz glavnyh komponent mezhregional'noj differenciacii denezhnyh dohodov naselenija // Finansy i kredit. - 2003. - № 1(115). - S. 50-54.

6. Trud zanjatost' v Rossii. 2015 : Stat. sb. / Rosstat. - M., 2015. - S. 274.

(C) Kabashova E. V., 2017. 